\section{Plant growth regulators alters antioxidant metabolisms in Solanum trilobatum L.: An underutilized medicinal herb}

\section{Nivedithadevi, M. Arivalagan and R. Somasundaram*}

Water Stress Physiology Lab, Department of Botany, Annamalai University, Annamalai Nagar 608 002, Tamil Nadu, India

\begin{abstract}
In this study, the changes in enzymatic and non-enzymatic antioxidants of Solanum trilobatum was estimated upon treatment with plant growth regulators (PGR) like Abscisic acid (ABA), Paclobutrazol (PBZ) and Salicylic acid (SA). The given treatments were started at 70th day followed by 80th, 90th and 100th Days After Sowing (DAS). The groups were treated with respect growth hormones by spraying method to ABA $10 \mu \mathrm{g} \mathrm{L}^{-1}$, PBZ $10 \mathrm{mg} \mathrm{L}^{-1}$ and SA $500 \mu \mathrm{g} \mathrm{L}-1$ concentrations. The plant was harvested on $80^{\text {th }}, 90^{\text {th }}, 100^{\text {th }}$ and $110^{\text {th }}$ DAS and analyzed the nonenzymatic antioxidants like Reduced glutathione (GSH), Ascorbic acid (AA) and $\alpha$ tocopherol contents and enzymatic antioxidants like Superoxide dismutase (SOD), Peroxidase (POX), Catalase (CAT) and Ascorbate peroxidase (APX) activities. In all the non-enzymatic and enzymatic antioxidant contents were increased by the growth regulators to a significant extent when compared with control plants. In our results indicated that the ABA, PBZ and SA applications at low concentration can be used as a potential tool to increase defence mechanisms in medicinal plants.
\end{abstract}

Key words:

Solanum trilobatum, plant growth regulators, abscisic acid, paclobutrazol, salicylic acid, antioxidant activity

\section{Received: \\ 04 May 2017}

Accepted:

09 June 2017

Published:

10 June 2017

*Corresponding Author:

R. Somasundaram

Water Stress Physiology

Lab, Department of

Botany, Annamalai

University, Annamalai

Nagar 608 002, Tamil

$\mathrm{Nadu}$, India

Email:

kalaisomu_20@

rediffmail.com

Citation:

Nivedithadevi, D.,

Arivalagan, M., \&

Somasundaram, R. (2017).

Plant growth regulators

alters antioxidant

metabolisms in Solanum

trilobatum L.: An

underutilized medicinal

herb. Journal of Medicinal

Botany, 1, 20-28. doi: 10.25081/jmb.2017.v1.51

\section{Introduction}

Solanum trilobatum L. belongs to the family Solanaceae. It is commonly available in Southern India and it has been used in herbal medicine to treat various diseases like cough (Mihira et al., 2011) diabetes, vomiting with blood and leprosy (Doss et al., 2011). Besides these, it is also used to increase male fertility and also counter acts snake poison (Govindhan et al., 2004). S. trilobatum possess pharmacological properties vi\%, antiasthmatic (Govindhan et al., 1999), anticancer (Mohanan and Devi, 1997) and antidandruff (Pant et al., 2013). The plant is also rich in phytochemical constituents like alkaloids, phenolics, flavonoids, sterols, saponins and glycosides (Amir and Kumar, 2004).
There are various studies on medicinal effects (Parasuraman et al., 2017; Kannan et al., 2016; Ahmed et al., 2016) and vegetable and edible aspects (Arinathan et al., 2007) but the effects of different plant growth regulators on this plant is still to be investigated.

Abscisic acid (ABA) as a plant growth reguators involved in many plant process like seed maturation, dormancy and adaptation to abiotic stresses (Beaudoin et al., 2000; Sreenivasulu et al., 2012). Paclobutrazol (PBZ) is a triazole group of systematic fungicide, and possesses regulating properties on plant growth (Fletcher and Arnold, 1986). The previous works were carried out in revealed that the 
morphological and physiological changes associated with the triazole treatment in various plants, including the inhibition of the plant growth, decreased intermodal elongation, increased chlorophyll levels, enlarged chloroplasts, thicker leaf tissue, increased root and shoot ratio, increased antioxidant potentials, and an enhancement in alkaloid productions (Jaleel et al., 2007). Salicylic acid (SA) is an endogenous plant growth regulator (Metraux, 2002) and plays many significant actions in plants like plant growth, thermogenesis, flower induction, nutrient uptake, ethylene biosynthesis, stomatal movements, photosynthesis and enzyme activities (Hayat and Ahmed, 2007).

The objectives of the present investigation were conducted to evaluate the effects of PGR such as ABA, PBZ and SA on enzymatic and non-enzymatic antioxidant changes of $S$. trilobatum under field conditions.

\section{Materials and methods}

Solanum trilobatum economically important medicinal plant belongs to the family Solanaceae was selected for the present investigation. The seeds were obtained from the Horticulture Department in Annamalai University, Chidambaram in Tamil Nadu, India. Paclobutrazol is a triazolic group of fungicide having plant growth regulating properties obtained from CULTAR 25\% w/v from Zeneca ICI Agrochemical Ltd., Mumbai, India. Abscisic acid and Salicylic acid were obtained from Himedia Mumbai.

\section{Plant material and cultivation method}

The field experiments were conducted at the Botanical Garden and Plant Growth Regulation Laboratory, Department of Botany, Annamalai University, Tamil Nadu, India, and as explained by us (Nivedithadevi et al., 2012).

The seeds were surface sterilized with $0.2 \%$ mercuric chloride solution for 2 min and rinsed thoroughly with distilled water. The seeds were soaked for 3 hours in conical flask before sowing. The nursery bed is prepared with clay, red loam soil and Farm yard manure (FYM) in 1:1:1 ratio. Then seeds were spread on the nursery bed. The plants were allowed to grow till 40 day with regular irrigation. The seedlings were selected with $10-12 \mathrm{~cm}$ height and develop 6 leaves for even growth conditions.
The field is laid out exactly as for ridged, irrigated sufficiently and, after ploughing twice, is watered heavily and ploughed again. FYM and neem cake will give as fertilizers. In the initial period, irrigation is done once in a week and then in later stages as per requirement. The selected plants were transplanted to field. After 70 day the treatments like PBZ at $10 \mathrm{mg} \mathrm{L}^{-1}$, $\mathrm{ABA}$ at $10 \mu \mathrm{g} \mathrm{\textrm {L } ^ { - 1 }}$ and $\mathrm{SA}$ at $500 \mu \mathrm{g} \mathrm{\textrm {L } ^ { - 1 }}$ were started at $70^{\text {th }}$ day followed by $80^{\text {th }}, 90^{\text {th }}$ and $100^{\text {th }}$ days. The groups were treated with respect growth hormones by spraying method. After every treatment of the $10^{\text {th }}$ day, the plants were harvested for further analysis.

\section{Determination of non-enzymatic antioxidants}

The reduced glutathione content was assayed as described by Griffith and Meister (1979) and expressed reduced glutathione content in $\mu \mathrm{g} g-1$ fresh weight $(\mathrm{FW})$. Ascorbic acid content was assayed as described by Omaye et al. (1979) and the results were expressed in $\mathrm{mg} \mathrm{g}^{-1}$ dry weight (DW). $\alpha$-tocopherol content was assayed as described by Backer et al. (1980) and expressed in $\mathrm{mg} \mathrm{g}^{-1}$ fresh weight (FW).

\section{Determination of enzymatic antioxidant activities}

The peroxidase activity was determined by the method of Reddy et al. (1995). One unit (U) of peroxidase is defined as the change in absorbance/min. at $430 \mathrm{~nm}$. Superoxide dismutase activity was assayed as described by Beauchamp and Fridovich (1971). SOD activity was expressed in units. One unit $(\mathrm{U})$ is defined as the amount of change in the absorbance by $0.1 \mathrm{~h}^{-1}$ $\mathrm{mg}^{-1}$ protein. The Ascorbic peroxidase activity was determined by the method of Asada and Takahashi (1987) and expressed in Umg-1 protein. The catalase activity was measured according to the method of Chandlee and Scandalios (1984). The enzyme activity is expressed in $\mathrm{U} \mathrm{mg}^{-1}$ protein. $\left(\mathrm{U}=1 \mathrm{mM}\right.$ of $\mathrm{H}_{2} \mathrm{O}_{2}$ reduction $\mathrm{min}^{-1} \mathrm{mg}^{-1}$ protein).

\section{Results}

\section{Non-enzymatic antioxidant contents}

The reduced glutathione content was increased all the growth regulators treated plants when compared to control. At 110 DAS PBZ treated plants GSH content was highest level increased on 430.87 per cent over control as 
followed by ABA (347.43\%) and SA (324.19\%). Among the treatments the highest GSH content was recorded in PBZ followed by ABA and SA in all sampling days.

The ascorbic acid content of the growth regulator treated $S$. trilobatum plant was increased in all the sampling days when compared to control. The plant ascorbic acid content of leaves and it was 414.60, 319.10 and 304.49 per cent over control respectively in PBZ, ABA and SA treated plant on 110 DAS. Among the treatments PBZ showed the higher ascorbic acid content.

In leaves of $S$. trilobatum plant $\alpha$-tocopherol content was increased by the growth regulator treated plant at all sampling days. Among the treatment PBZ highly increased the $\alpha$-tocopherol content and it was 186.44 per cent over control followed by ABA 162.63 and SA 145.78 per cent over control and on 110 DAS.

\section{Antioxidant enzymes activities}

The peroxidase content of the growth regulator treated $S$. trilobatum plant was increased in all the sampling days when compared to control. Peroxidase content was greater than 211.80 per cent in the ABA treated plants and also PBZ and SA reasonably increased the peroxidase activity was 180.74 and 168.94 per cent over control plants on 110 DAS. Among the treatments the highest peroxidase content was recorded in ABA followed by PBZ and SA in all sampling days.

In all the sampling days the SOD activity was increased when compared to control. The 110 DAS ABA treated plant recorded highest SOD content was found in 189.01 per cent, followed by PBZ (158.58\%) and SA (133.40\%) over control plants. Among the treatments the highest SOD content was recorded in ABA followed by PBZ and SA in all sampling days.

Ascorbate peroxidase activity was increased in all the treatment plants when compared to control. In 110 DAS the ABA treated plants 227.16 per cent followed by PBZ and SA treated plants showed the minimal increased as 218.96 and 174.23 per cent over control respectively. Among the treatments the highest ascorbate peroxidase activity was recorded in $\mathrm{ABA}$ followed by PBZ and SA in all sampling days.

When compared with control plants, the increased CAT activity was found to be 275.72 per cent in ABA treated plants, followed by PBZ in 215.22 and SA 200.41 per cent over control for 110 DAS. The highest catalase activity was recorded in $\mathrm{ABA}$ followed by $\mathrm{PBZ}$ and $\mathrm{SA}$ in all sampling days.

Table 1. Effect of different growth regulators on antioxidant variations of $S$. trilobatum in different growth stages.

\begin{tabular}{|c|c|c|c|c|}
\hline DAS & Control & $\mathrm{ABA}$ & PBZ & $\mathrm{SA}$ \\
\hline \multicolumn{5}{|c|}{ Reduced Glutathione } \\
\hline 80 & $0.505 \pm 0.02^{\mathrm{a}}$ & $1.520 \pm 0.01^{c}$ & $1.917 \pm 0.01^{\mathrm{d}}$ & $1.145 \pm 0.01^{b}$ \\
\hline 90 & $0.635 \pm 0.02^{\mathrm{a}}$ & $1.955 \pm 0.01^{c}$ & $2.485 \pm 0.01^{\mathrm{d}}$ & $1.735 \pm 0.03^{\mathrm{b}}$ \\
\hline 100 & $0.755 \pm 0.04^{\mathrm{a}}$ & $2.542 \pm 0.02^{c}$ & $3.090 \pm 0.02^{\mathrm{d}}$ & $2.282 \pm 0.02^{\mathrm{b}}$ \\
\hline 110 & $0.839 \pm 0.02^{\mathrm{a}}$ & $2.915 \pm 0.12^{\mathrm{c}}$ & $3.615 \pm 0.01^{\mathrm{d}}$ & $2.720 \pm 0.21^{\mathrm{b}}$ \\
\hline \multicolumn{5}{|c|}{ Ascorbic acid } \\
\hline 80 & $1.06 \pm 1.34^{\mathrm{a}}$ & $3.04 \pm 2.60^{c}$ & $3.80 \pm 2.59 \mathrm{~d}$ & $2.76 \pm 5.54^{b}$ \\
\hline 90 & $1.32 \pm 1.95^{\mathrm{a}}$ & $3.88 \pm 1.88^{c}$ & $4.98 \pm 1.65^{\mathrm{d}}$ & $3.67 \pm 2.18^{\mathrm{b}}$ \\
\hline 100 & $1.54 \pm 1.67^{\mathrm{a}}$ & $4.72 \pm 2.54^{c}$ & $6.18 \pm 2.11^{\mathrm{d}}$ & $4.58 \pm 3.41^{b}$ \\
\hline 110 & $1.78 \pm 2.39^{\mathrm{a}}$ & $5.68 \pm 4.48^{c}$ & $7.38 \pm 3.16^{\mathrm{b}}$ & $5.42 \pm 9.55^{\mathrm{d}}$ \\
\hline \multicolumn{5}{|c|}{$\alpha$-tocopherol } \\
\hline 80 & $2.02 \pm 0.20^{\mathrm{a}}$ & $2.71 \pm 0.54^{\mathrm{c}}$ & $3.27 \pm 0.11^{\mathrm{d}}$ & $2.22 \pm 0.07^{b}$ \\
\hline 90 & $2.26 \pm 0.36^{\mathrm{a}}$ & $3.34 \pm 0.24^{c}$ & $3.89 \pm 0.06^{\mathrm{d}}$ & $2.72 \pm 0.56^{\mathrm{b}}$ \\
\hline 100 & $2.52 \pm 0.38^{\mathrm{a}}$ & $3.89 \pm 0.11^{\mathrm{c}}$ & $4.56 \pm 0.04^{d}$ & $3.35 \pm 0.04^{b}$ \\
\hline 110 & $2.73 \pm 0.55^{\mathrm{a}}$ & $4.45 \pm 0.06^{\mathrm{c}}$ & $5.09 \pm 0.01^{\mathrm{d}}$ & $3.98 \pm 0.70^{\mathrm{b}}$ \\
\hline
\end{tabular}

Values are given as mean \pm SD. of six samples in each group. Bar values are not sharing a common superscript (a, b, c, d) differ significantly at $\mathrm{P} \leq 0.05$ (DMRT). 


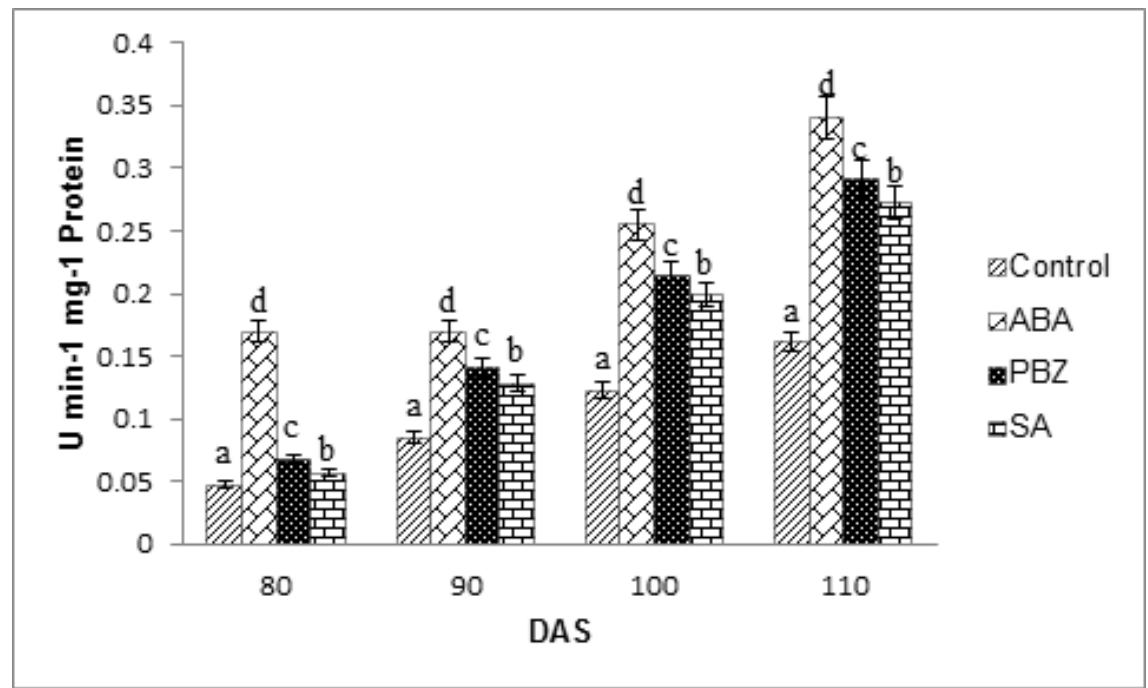

Fig. 1. Effect of different growth regulators treatments on the peroxidase activity in S. trilobatum on different growth stages. Values are given as mean \pm SD. of six samples in each group. Bar values are not sharing a common superscript ( $a, b, c, d)$ differ significantly at $\mathrm{P} \leq 0.05$ (DMRT).

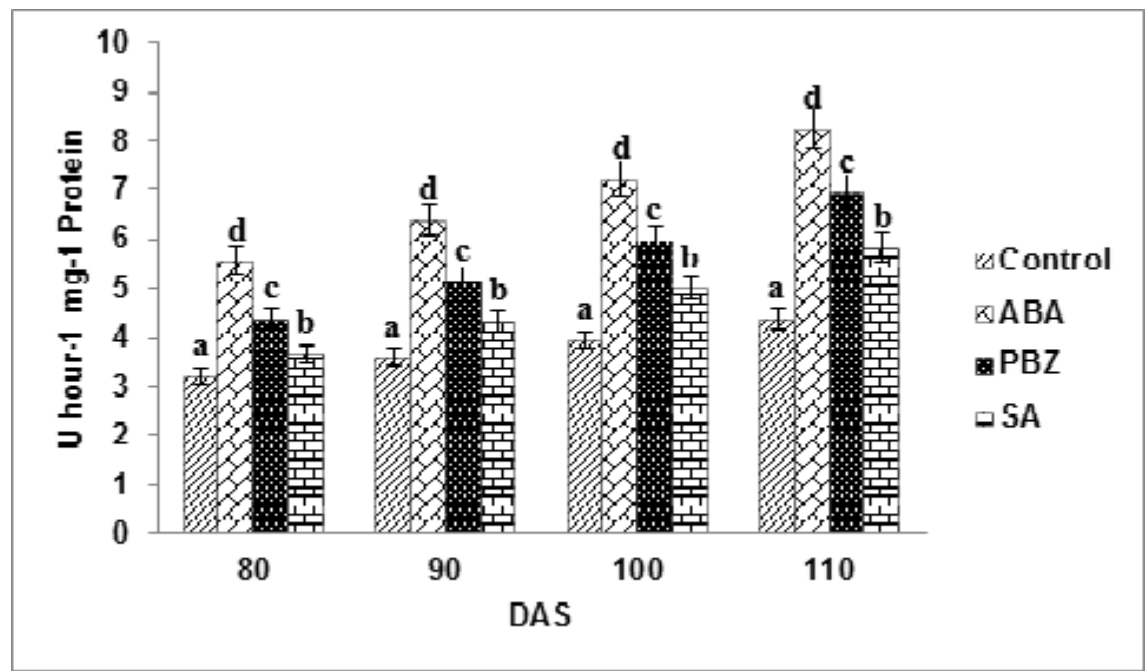

Fig. 2. Effect of different growth regulators treatments on the superoxide dismutase activity in $S$. trilobatum on different growth stages. Values are given as mean \pm SD. of six samples in each group. Bar values are not sharing a common superscript (a, b, c, d) differ significantly at $\mathrm{P} \leq 0.05$ (DMRT).

\section{Discussion}

The GSH content of the plant increased with the age in control and growth regulators treated S. trilobatum. All the three growth regulators were increased the GSH content significantly when compared to control. The similar report was observed at paclobutrazol (Sivakumar and
Panneerselvam, 2011) in Datura metal. SA pretreatment significantly accelerated the accumulation of glutathione content in wheat (Kang et al., 2013). Our results also show that application of SA significantly increases the content reduced glutathione content. 


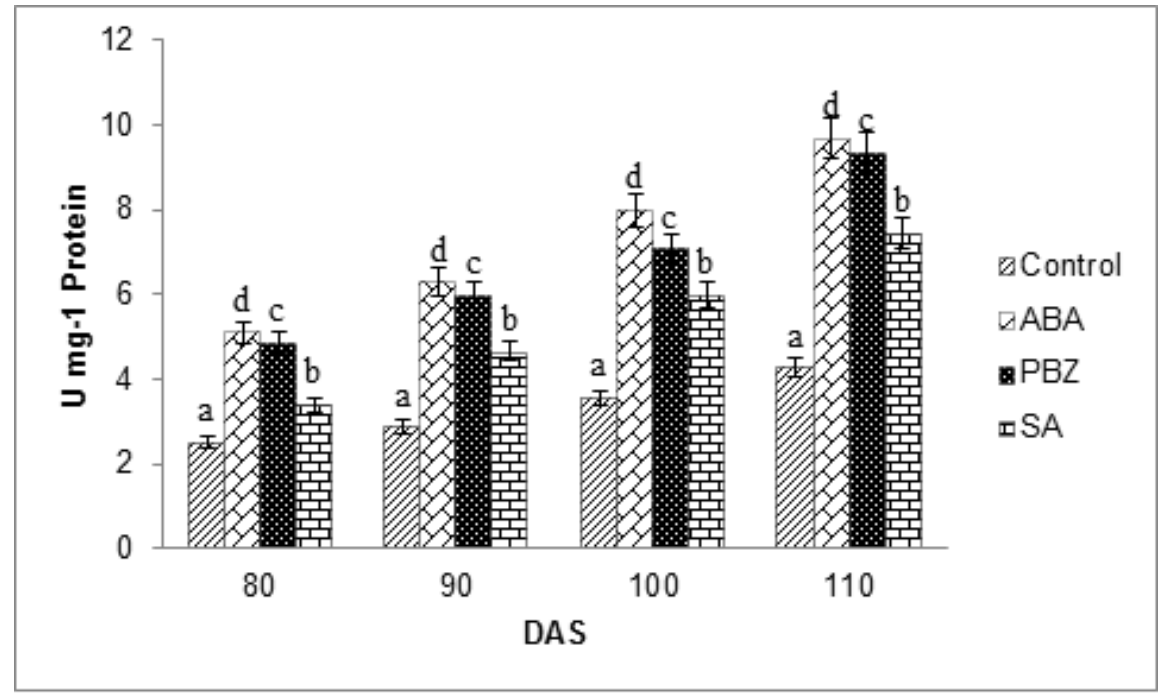

Fig. 3. Effect of different growth regulators treatments on the ascorbic peroxidase activity in $S$. trilobatum on different growth stages. Values are given as mean \pm SD. of six samples in each group. Bar values are not sharing a common superscript (a, b, c, d) differ significantly at $\mathrm{P} \leq 0.05$ (DMRT).

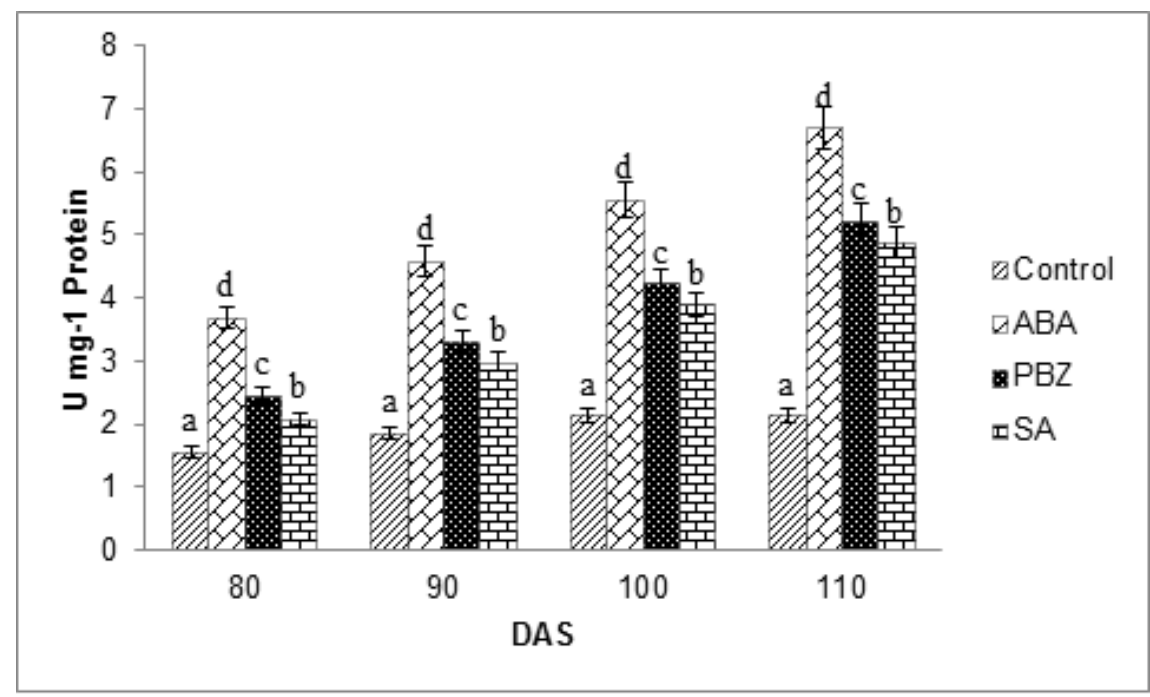

Fig. 4. Effect of different growth regulators treatments on the catalase activity in S. trilobatum on different growth stages. Values are given as mean $\pm \mathrm{SD}$. of six samples in each group. Bar values are not sharing a common superscript (a, b, c, d) differ significantly at $\mathrm{P} \leq 0.05$ (DMRT).

AA acts as an antioxidant, protecting cells against oxidative stress. AA is found to be one of the best characterized compounds, required for many key metabolic functions in plant cells (Smirnoff and Wheeler, 2000). In the present investigation, it was observed that growth regulators treated $S$. trilobatum plant increased AA content when compared to control plants. Similar findings were made in ABA increased (Guo et al., 2012). Increase in ascorbic acid content was reported in the triazole treated Helianthus annus and Vigna unguiculata (Manivannan et al., 2008). Then SA pretreatment significantly accelerated the accumulation of GSH and AA in eggplant (Chen et al., 2011).

The growth regulator treatment to increase $\alpha$-tocopherol content of the $S$. trilobatum plant when compared to control. Similar observations were made $\mathrm{ABA}$ increases in Lactuca sativa (Al 
Muhairi et al., 2015). Then triazole increased the level of antioxidant ascorbic acid and $\alpha$ tocopherol like in tomato seedlings and Helianthus annuus protected the membrane by preventing or reducing oxidative damage (Amalan Rabert et al., 2013). The SA treatments increased the $\alpha$-tocopherol content from other worker (Munne-Bosch and Penuelas, 2003).

The SOD activity of the $S$. trilobatum was increased on various growth regulating treatments when compared to control. Similar to our results, some report has showed the growth regulator to induce an increase SOD activity. $\mathrm{ABA}$ increases the activities of antioxidant enzymes on two previous studies, such as SOD, catalase, APX and glutathione reductase in plant tissues under drought and freezing stress (Bano et al., 2012; Yang et al., 2013). The results are similar to those of triazole treatments in Capsicum annuum (Amalan Rabert et al., 2013). There are data supporting the claim that SA increases the activities of antioxidant enzymes (Ali Ghasemzadeh and Hawa, 2013; Pirasteh Anosheh et al., 2012).

In the present study growth regulators treatment results in $S$. trilobatum was increase of the APX activity when compared to control. Results of present investigation are consistence with the findings of $\mathrm{ABA}$ increased the APX content in (Zhang et al., 2014). Triazole treatment increased APX activity when compared to the case of control and droughtstressed plants (Manivannan et al., 2007; Amalan Rabert et al., 2014). Increasing APX activity as a consequence of exogenous SA application was also reported by (Krantev et al., 2008; Mishra et al., 2013).

The CAT activity was increased all the growth regulator treatments when compared to control. Similar results were obtained by many workers in many higher plants under ABA, PCZ and SA treated plants. ABA increased the CAT activity was observed by (Divya Nair et al., 2009) in Ocimum sanctum. The triazole treatments an increase in catalase activity was reported in higher plants when compared to control plants were noted in tomato and Solenostemon rotundifolius (Mohamadi and Rajaei, 2013; Kishorekumar et al., 2008). SA application was also increased in CAT and POX in heat stress (Kaur et al., 2009; Orabi et al., 2010).
The S. trilobatum plant POX activity was increased significantly at growth regulator treatments when compared to control. These results are in conform to the observations carried out by (Basak et al., 2012) in ABA treatment. Then activities of POX have been increased by the triazole application observed in Withania somnifera (Jaleel et al., 2008; Hojati et al., 2011). Then SA treatment increased the POX activities when compared to control this results agree with (Chen et al., 2014) in Zoysia japonica.

\section{Conclusion}

From the results of this investigation, it is clear that, the growth regulators $\mathrm{ABA}, \mathrm{PBZ}$ and $\mathrm{SA}$ treatments were increased the $\mathrm{AA}, \alpha$ tocopherol and GSH of S. trilobatum. Antioxidant enzymes like, APX, SOD, POX and CAT were increased using the above treatments in $S$. trilobatum. In conclusion, our results indicated that the ABA, PBZ and SA applications at low concentration can be used as a potential tool to increase defense mechanisms in medicinal plants.

\section{Author contributions}

D.N and M.A worked under the supervision of R.S. All authors participated in the writing of the manuscript. All the authors agreed the final version of manuscript for publishing in Journal of Medicinal Botany.

\section{References}

Ahmed, Z., Syed, K., Sidhra, A., Zameer, S., Ponmurugan, P., \& Kumar, B. S. (2016). Ameliorative potential of Solanum trilobatum leaf extract and fractions on lipid profile and oxidative stress in experimental diabetes. Pakistan journal of pharmacentical sciences, 29(5).

Al Muhairi MA, Jaleel CA, Kurup SS, Rabert GA, Mohammad S (2015) Effect of abscisic acid on biochemical constituents, enzymatic and non-enzymatic antioxidant status of lettuce (Lactuca sativa L.) under varied irrigation regimes. Cogent Food Agricul 110.

Ali Ghasemzadeh, Hawa Z E (2013) Interactive Effect of Salicylic Acid on Some Physiological Features and Antioxidant Enzymes Activity in Ginger (Zingiber officinale Roscoe). Molecules 18: 5965-5979.

Amalan Rabert G, Manivannan P, Somasundaram R, Panneerselvam R (2014) 
Triazole compounds alters the antioxidant and osmoprotectant status in drought stressed Helianthus annuus L. plants. Emir J Food Agric 26 (3):265.

Amalan Rabert G, Rajasekar M, Manivannan P, Somasundaram R, Panneerselvam R (2013) Effect of triazole fungicide on biochemical and antioxidant enzymes activity in Okra (Abelmoschus esculentus 1.) Plant under drought stress. Inter J Agri Food Sci 3(3): 100-107.

Amir M, Kumar S (2004) Possible industrial application of genus Solanum in twenty first century- A review. J Scie Ind Res 63: 116124.

Arinathan, V., Mohan, V. R., Britto, A., \& Murugan, C. (2007). Wild edibles used by Palliyars of the western Ghats, Tamil Nadu.

Asada K, Takahashi M 1987. Production and scavenging of active oxygen in photosynthesis. In: Kyle, D.J., Osmond, B., Arntzen, C.J. (Eds.), Photoinhibition, Amsterdam Elsevier 227-287.

Backer H, Frank O, De Angells B, Feingold S (1980) Plasma tocopherol in man at various times after ingesting free or ocetylaned tocopherol. Nutr Rep Int 21: 531-536.

Bano A, Ullah F, Nosheen A (2012) Role of abscisic acid and drought stress on the activitiesof antioxidant enzymes in wheat. Plant Soil Environ 58(4): 181-185.

Basak H, Demir K, Doganlar ZB (2012) The Effect Of Abscisic Acid Application On Root-Shoot Length And Some Antioxidant Enzyme Activities Of Two Different Tomato Seedlings. J Animal Plant Scie 22(3): 695-703.

Beauchamp CO, Fridovich I (1971) Superoxide dismutase: Improved assays and an assay applicable to acrylamide gels. Ann Biochem 44: 276-287.

Beaudoin N, Serizet C, Gosti F, Giraudat J (2000) Interactions between abscisic acid and ethylene signiling cascades. Plant Cell 12: 1103-1116.

Chandlee JM, Scandalios JG (1984) Analysis of variants affecting the catalase development program in maize scutellum. Theor Appl Gen 69: 71-77.

Chen S, Liu Z, Cui J, Ding J, Xia X, Liu D, Yu J (2011) Alleviation of chilling-induced oxidative damage by salicylic acid pretreatment and related gene expression in eggplant seedlings. Plant Growth Regul 65: 101-108.

Chen ZL, Li XM, Zhang LH (2014) Effect of Salicylic Acid Pretreatment on Drought Stress Responses of Zoysiagrass (Zoysia japonica)1. Russ J Plant Physio 61(5): 619625.

Divya Nair V, Abdul Jaleel C, Gopi R, Gomathinayagam M, Panneerselvam R (2009) Antioxidant potential of Ocimum sanctum under growth regulator treatments. Eur Asia J BioSci 3: 1-9.

Doss A, Palaniswamy M, Angayarkanni J, Dhanabalan R (2011) Antidiabetic activity of water extract of Solanum trilobatum (Linn) in alloxan-induced diabetes in rats. Afri J Biotech 8(20): 5562-5564.

Fletcher RA, Arnold V (1986) Stimulation of cytokinins and chlorophyll synthesis in cucumber cotyledons by triadimefon. Physiol Plant 66: 197-201.

Govindhan S, Viswanathan S, Vijayasekaran V, Alagappan R (1999) Pilot study on the clinical efficacy of Solanum xanthocarpum and Solanum trilobatum in bronchial asthma. J Ethnophar 66: 205-210.

Govindhan, S., Viswanathan, S., Viyasekaran, V., and Alagappan, R. 2004. Clinical efficacy of Solanum xanthocarpum and Solanum trilobatum in bronchial asthma. Int. J. Phytotherapy Res. 18(10): 805-809.

Griffith OW, Meister A (1979) Potent and specific inhibition of glutathione synthesis by buthionine sulfoximine (s-nbutylhomocysteine sulfoximine). J Biol Chem 254: 7558-7560.

Guo WL, Chen RG, Gong ZH, Yin YX, Ahmed SS, He YM (2012) Exogenous abscisic acid increases antioxidant enzymes and related gene expression in pepper (Capsicum annuиm) leaves subjected to chilling stress. Genet Mole Res 11(4): 4063-4080.

Hayat S, Ahmed A (2007) Salicylic acid: A plant hormone. Springer, Dordrecht, The Netherland, 1-14.

Hojati M, Mohammad S, Sanavy M, Ghanati F, Panahi M (2011) Hexaconazole induces antioxidant protection and apigenin-7glucoside accumulation in Matricaria 
chamomilla plants subjected to drought stress. J Plant Physio 168: 782-791.

Jaleel CA, Gopi R, Manivannan P, Kishorekumar A, Gomathinayagam M, Panneerselvam R (2007a) Changes in biochemical constituents and induction of early sprouting by triadimefon treatment in white yam (Dioscorea rotundata Poir.) tubers during storage. J Zhejiang Univer Sci 8: 283-288.

Jaleel CA, Gopi R, Manivannan P, Panneerselvam R (2008) Exogenous application of triadimefon affects the antioxidant defense system of Withania somnifera Dunal. Pesticide Bioche Physio 91: 170-174.

Kang GZ, Li GZ, Liu GQ, Xu W, Peng XQ, Wang CY, Zhu YJ, Guo TC (2013) Exogenous salicylic acid enhances wheat drought tolerance by influence on the expression of genes related to ascorbateglutathione cycle. Biologia Plantarum 57(4): 718-724.

Kannan, K. P., Govindasamy, R., Rajendran, R., Manaogaran, S., \& Dhakshinamoorthy, M. (2016). Hydrocarbons from curvularia lunata-a novel promising endophytic fungi isolated from solanum trilobatum linn. International Journal of Chemistry, Pharmacy \& Technology, 1, 10-7.

Kaur P, Ghai N, Sangha MK (2009) Induction of thermotolerance through heat acclimation and salicylic acid in Brassica species. African J Biotechnol 8(4): 619-625.

Kishorekumar A, Jaleel CA, Manivannan P, Sankar B, Sridharan R, Murali PV, Panneerselvam R (2008) Comparative effects of different triazole compounds on antioxidant metabolism of Solenostemon rotundifolius. Colloids Surf B Biointerfaces 62: 307-311.

Krantev A, Yordanova R, Janda T, Szalai G, Popova L (2008) Treatment with salicylic acid decreases the effect of cadmium on photosynthesis in maize plants. J Plant Physiol 165: 920-931.

Manivannan P, Jaleel CA, Kishorekumar A, Sankar B, Somasundaram R, Sridharan R, Panneerselvam R (2007) Changes in antioxidant metabolism of Vigna unguiculata (L.) Walp. by propiconazole under water deficit stress. Colloids Surf B Biointer 57: 69-74.

Manivannan P, Jaleel CA, Somasundaram R, Panneerselvam R (2008) Osmoregulation and antioxidant metabolism in drought-stressed Helianthus annuus under triadimefon drenching. C R Biologies 331: 418-425.

Metraux JP (2002) Recent breakthroughs in the study of salicylic acid biosynthesis. Trends Plant Sci 7: 332-334.

Mihira V, Ramana KV, Ramakrishna S, Kumar P (2011) Evaluation of antimicrobial activity of Solanum trilobatum Linn. roots. Res J Pharmaceu Bio Chem Scie. 2(2-3): 158-160.

Mishra M, Kumar U, Prakash V (2013) Influence of Salicylic acid pre-treatment on water stress and Its relationship with antioxidant status in glycine max. Int J Pharm Bio Sci 4(4): 8-97.

Mohamadi N, Rajaei P (2013) Effect of Triamidefon fungicide on some growth parameters and antioxidant enzymes activity in tomato (Lycopersicom esculentum Mill.) plant under drought stress. Int J Adv Biol Biom Res 1(4): 341-350.

Mohanan PV, Devi KS (1997) Toxicological evaluation of Solanum trilobatum. Cancer Letter 1127:135-140.

Munne-Bosch S, Penuelas J (2003) Photo- and antioxidative protection, and a role for salicylic acid during drought and recovery in field-grown Phillyrea angustifolia plants. Planta 217: 758-766.

Nivedithadevi, D., Somasundaram, R., \& Pannerselvam, R. (2012). Effect of abscisic acid, Paclobutrazol and Salicylic acid on the growth and pigment variation in Solanum trilobatum (L). Int. J. Drug Dev. \& Res., 4(3): 236- 246.

Omaye ST, Turnbull JD, Sauberilich HE (1979) Selected methods for the determination of ascorbic acid in animal cells, tissues and fluids. Methods in Enzymology. Academic Press. 3-11.

Orabi SA, Salman SR, Magda AF (2010) Increasing Resistance to Oxidative Damage in Cucumber (Cucumis sativus L.) Plants by Exogenous Application of Salicylic Acid and Paclobutrazol. World J Agricul Scie 6(3): 252-259.

Pant G, Nayak NR, Prasuna G (2013) Enhancement of antidandruff activity of 
shampoo by biosynthesized silver nanoparticles from Solanum trilobatum plant leaf. J Nanosci Nanotech 3: 431-439.

Parasuraman, S., Chuen, L. Y., Hoong, S. S., De Wei, D. L., Zou, L. N., \& Loshini, S. (2017). Poor antimicrobial activity of methanol and ethanol extract of leaves of Solanum trilobatum Linn. Journal of Pharmaceutical Negative Results, 8(1), 53.

Pirasteh Anosheh H, Emam Y, Ashraf M, Foolad MR (2012) Exogenous Application of Salicylic Acid and Chlormequat Chloride Alleviates Negative Effects of Drought Stress in Wheat. Advance Stud Bio 4(11): 501-520.

Reddy KP, Subhani SM, Khan PA, Kumar KB (1995) Effect of light and benzyl adenine on dark-treated growing rice leaves. II. Changes in peroxidase activity. Plant and Cell Physiology 24: 987-994.

Sivakumar T, Panneerselvam R (2011) Triadimefon Mediated change in antioxidant and indole alkaloid content in two species of Datura. Ameri J Plant Physio 6(5): 252-260.
Smirnoff N, Wheeler GL (2000) Ascorbic acid in plants: Biosynthesis and function. Crit. Rev. Plant Sci 19: 267-290.

Sreenivasulu N, Harshavardhan VT, Govind G, Seiler C, Kohli A (2012) Contrapuntal role of ABA: Does it mediate stress tolerance or plant growth retardation under long-term drought stress?. Gene 506(12): 265-273.

Yang H, Li H, Rao LQ, Long GY, Shi GR, Peng GP (2013) Effects of exogenous ABA on antioxidant enzymes in detached citrus leaves treated by rapid freezing. African J Biotech 10: 9779-9785.

Zhang L, Li X, Zhang L, Li B, Han M, Liu F, Zheng P, Alva AK (2014) Role of abscisic acid (ABA) in modulating the responses of Two apple rootstocks to drought stress. Pak J Bot 46(1): 117-126. 